\title{
Evaluation of Hematological and Metabolic Parameters in Small Ruminants with Trace Elements Deficiency under Different Biogeochemical Conditions
}

\author{
Vladimir Vorobyov $^{1}$, Dmitry Vorobyov $^{1}$, Petr Polkovnichenko $^{1}$ and Vladimir Safonov $^{2 *}$ \\ ${ }^{I}$ Astrakhan State University, Astrakhan, Astrakhan Oblast, Russia \\ ${ }^{2}$ Vernadsky Institute of Geochemistry and Analytical Chemistry of the Russian Academy of Sciences, Moscow, Russia \\ *Corresponding author’s Email: v1safonov@rambler.ru, (D) ORCiD: 0000-0002-5040-6178
}

\begin{abstract}
In the present study soil, water, pasture plants, organs and tissues of crossbred sheep of the Soviet Aksaray and Zaanen German White Improved goats were analyzed for their Selenium (Se), Iodine (I), Cobalt (Co), zinc, copper, and manganese content in the Lower Volga region. The biogeochemical situation of terrestrial ecosystems of the Lower Volga region was characterized by Se, Co, and I deficiencies in soil, water, pasture plants, and feed of crossbred sheep of the Soviet Aksaray and Zaanen German White Improved goats. The deficiency of these trace elements in small ruminants had been compensated by changes in hematological parameters include high Red Blood Cell (RBC) and White Blood Cell (WBC) and biochemical parameters. Meanwhile, the analyzed trace elements in the organs and tissues of crossbred sheep $(n=6)$ and Zaanen German white improved goats $(n=6)$ demonstrated that goats had lower amounts of Se $(0.0136 \pm 0.002 \mathrm{mg} / \mathrm{kg}), \mathrm{I}(0.19 \pm 0.01 \mathrm{mg} / \mathrm{kg})$, and Co $(0619 \pm 0.03 \mathrm{mg} / \mathrm{kg})$ compared to sheep. The animals were recorded with a decrease in alkali reserve, the content of total protein and lipids, vitamins A, E, C, B12, total calcium, and inorganic phosphorus, increase in glucose, conjugated dienes and malonic di-aldehyde in the blood, and functional insufficiency of the antioxidant protection system.
\end{abstract}

Key words: Biogeochemistry, Goat, Metabolism, Micronutrient deficiency, Sheep, Trace elements deficiency.

\section{INTRODUCTION}

The Lower Volga region (Russia) was characterized by Selenium (Se), Iodine (I), and Cobalt (Co) deficiency in soil and pasture plants that form the core of sheep's and goats' feed (Kabata-Pendias, 2001; Bevis, 2015; Dinh et al., 2017; Ermakov, 2017). The largest amount of Se was found in May $(0.051 \pm 0.006 \mathrm{mg} / \mathrm{kg})$, and the smallest in the autumn $(0.024 \pm 0.003 \mathrm{mg} / \mathrm{kg})$. The Se content in pasture plants of the region was ranged from $12.6 \pm 0.2$ to $0.008 \pm 0.002 \mathrm{mg} / \mathrm{kg}$ in dry matter (Vorobyov et al., 2018). Most plants of the region had Co and I deficiency (Ermakov, 2017). These trace elements deficiencies in the animal's diet would be a stress factor leading to metabolic disorders, as well as decreasing productivity and reproductive function (Howard et al., 2016). Different species of small ruminants were known to have some differences in the accumulation of trace elements in the conditions of their biogeochemical deficit (Howard et al., 2016). According to Howard et al. (2016), differences in Cupper (Cu), Zink (Zn), and Manganese (Mn) content in milk of sheep and goats grazed on the same semi-desert pastures in Pakistan revealed the deficient in these elements. Meanwhile, they did not found any differences in Co and Se content in the milk of these animals. Given the absence of research on the concentration of trace elements in the body of sheep and goats living in the Lower Volga region (Astrakhan region), the present study aimed to measure the content of $\mathrm{Se}, \mathrm{I}, \mathrm{Co}, \mathrm{Zn}, \mathrm{Cu}$ and $\mathrm{Mn}$ in soil, water, fodder plants, diets, organs and tissues of sheep and goats living in the given area. The influence of these trace elements on the animals' hematological and biochemical profile was also evaluated.

\section{MATERIALS AND METHODS}

\section{Ethical approval}

All experiments were performed in accordance with the animals act 1986 as recommendations of Amendment Regulations 2012, guide for the care and use of laboratory animals and on the basis of the Animal Ethics Committee report of Vernadsky Institute of Geochemistry and Analytical Chemistry of the Russian Academy of Sciences (Certificate No. 05.2017).

\section{Animals and research design}

Animals were selected randomly, from registered farms of Astrakhan Oblast in Russia. In the first stage, the content of trace elements ( $\mathrm{Se}, \mathrm{I}, \mathrm{Co}, \mathrm{Zn}, \mathrm{Cu}$ and $\mathrm{Mn})$ was analyzed in samples of soil ( $\mathrm{n}=302)$, water $(\mathrm{n}=26)$, pasture plants $(n=29)$, organs and tissues (skeletal muscle, liver, spleen, blood, lungs, kidneys, abomasum, small intestine, bone 
tissue, and wool) $(n=201)$ of Soviet Aksaray-type crossbreeding sheep $(n=6)$ and Zaanen German White Improved $(\mathrm{ZGWI})$ goats $(\mathrm{n}=6)$ in peasant farms in the Astrakhan region. Samples of soil, water, and plants were selected through the Kabata-Pendias method (2001). In the second stage, the researchers studied the influence of the elemental status of 3 years-old crossbred ewes of Soviet Aksaray-type sheep $(n=6)$ with a live weight of $51.2 \pm 2.6 \mathrm{~kg}$ and 3 -years-old ZGWI goats $(n=6)$ with a live weight of $32 \pm 1.4 \mathrm{~kg}$ on their hematological and biochemical profile. The study was held in the Unitary Municipal Agricultural Enterprise "Aksarayskiy" Krasnoyarsk district of the Astrakhan region. The studies were conducted in 2016-2019 in the spring and summer.

\section{Sampling}

Water samples were taken from rivers that are typical for the given area, specifically from the surface water and bottom sediments. The structure of polluted fields as well as geological and chemical factors that led to the formation of these areas were taken into account. Soil sampling for analysis has been carried out by the envelope method, after which the sample has been placed in a sample tube of chemically neutral material and delivered to the laboratory.

The selection of grass has been carried out immediately before processing it into feed. Nine sites have been allocated with an area of 1-2 $\mathrm{m}^{2}$, located diagonally. The samples (mean $450 \mathrm{~g}$ ) have been taken from each site and a combined sample was prepared with average weight of $1.2 \mathrm{~kg}$. During histological and histochemical studies, tissues have been fixed in a $10 \%$ solution of neutral formalin. Further, the tissues of the studied animals have been cut across into three plates of the same thickness: upper, middle and lower. The fast blood samples were collected form animals in the morning by puncture of the ear vein in the sterile EDTA vacuum blood collection tubes without anticoagulant blood was taken by puncture of the jugular vein into vacuum test-tubes, for hematology-with an anticoagulant, for biochemistry without an anticoagulant (serum). The blood samples have been centrifuged at 4000 rounds per minute for 10 minutes, after coagulation for an hour at room temperature. The blood serum was carefully collected and stored at $-20^{\circ}$ centigrade until biochemical analysis.

\section{Determination of trace elements contained in the samples}

The $\mathrm{Co}, \mathrm{Zn}, \mathrm{Cu}$ and $\mathrm{Mn}$, Se and I contained in the samples were determined using Hitachi 180-50 atomic absorption spectrophotometer.

\section{Hematological analysis}

Hemoglobin, erythrocytes, and leukocytes were determined by using a Micros-60 Analyzer (Horiba ABX, France). Differential number of leukocytes (leukocyte formula) was determined through disturbing a fine drop of venous blood on a slide, air-drying and staining with Romanovsky stains using May-Grunewald-Giemsa (MGG) method. Thereafter, two hundred cells were counted, classified, and their percentage was determined (Diem and Theml, 2004).

\section{Biochemical analysis}

The content of total calcium, inorganic phosphorus, and blood alkaline reserve, the range of total protein, lipids and glucose in the serum was determined using the relevant methods described in the references (Woodman and Price, 1972; Georgievskii et al., 1982; Choleva et al., 2018). The serum content of vitamins A and E was measured by liquid chromatography (Urbánek et al., 2006) using the MINICHROM columns with a UV scanning detector (Russia). The liquid chromatography technique was developed in Russia. It implies the use of multi-wavelength scanning spectrophotometric UV/V is detectors, fluorimetric detection, and the acquisition of spectra in the stopped-flow. The range of vitamin B12 was determined by the microbiological techniques with the Escherichia coli strains 115-6115-6 (Bandeli and Tuschhoff, 1954). The "Shimadzu UV-1700 series" spectrophotometer was used to determine the range of conjugated dienes, the primary products of lipid peroxidation (Pryor and Castle, 1984), malonic dialdehyde (Kazimirskii et al., 2018), catalase activity (Hadwan and Ali, 2018), superoxide dismutase (Guemouri et al., 1991), glutathione peroxidase (Paglia and Valentine, 1967) and erythrocyte acid resistance (Pokrovskii and Abrarov, 1964).

\section{Statistical analysis}

The software STATISTICA 8.0 (StatSoft. Inc., USA) was used for processing statistical data. The data provided the arithmetic mean \pm standard error of the mean; the coefficient of variation; and the correlation coefficients of Spearman and Pearson. The significant differences between groups of animals were determined by the Student's t-test with a significance level of $\mathrm{P}<0.05$.

\section{RESULTS}

The containing elements in water were $0.6 \pm 0.01 \mathrm{mg} / \mathrm{kg}$ of $\mathrm{Co}, 0.016 \pm 0.003 \mathrm{mg} / \mathrm{kg}$ of Se, $10.8 \pm 0.8 \mathrm{mg} / \mathrm{kg} \mathrm{of} \mathrm{Mn}$, $34.6 \pm 3.5 \mathrm{mg} / \mathrm{kg}$ of $\mathrm{Zn}, 3.7 \pm 0.6 \mathrm{mg} / \mathrm{kg}$ of $\mathrm{Cu}$, and $1.5 \pm 0.19 \mathrm{mcg} / \mathrm{kg}$ of I. The content of Se in the organs and tissues of 
ewes and goats lined up in decreasing order of liver, abomasum, spleen, wool, lungs, bone tissue, blood, kidneys, and skeletal muscle. The content of Co in the organs and tissues of ewes and goats lined up in decreasing order of wool, liver, abomasum, blood, bone tissue, lungs, kidneys, small intestine, and skeletal muscles. The content of I in the organs and tissues of ewes and goats lined up a decreasing order of spleen, abomasum, small intestine, kidneys, blood, bone tissue, wool, liver, lungs, and skeletal muscle. The highest concentration of Se was found in the liver of ewes $(0.57 \pm$ $0.003 \mathrm{mg} / \mathrm{kg})$, and in the kidneys of goats $(0.51 \pm 0.002 \mathrm{mg} / \mathrm{kg})$. The highest concentration of copper was found in the lungs $(19.8 \pm 1.07 \mathrm{mg} / \mathrm{kg})$ and in the small intestinal walls, with the level $0.05 \mathrm{mg} / \mathrm{kg}$ lower compared to lungs. The highest concentration of $\mathrm{Cu}$ was in the lungs of goats, which was $0.05 \pm 0.02 \mathrm{mg} / \mathrm{kg}$ higher than in the ewes. Ewes had the highest concentration of $\mathrm{Mn}$ in the blood $(55.7 \pm 0.09 \mathrm{mg} / \mathrm{kg})$, which was higher than in goats $(6.1 \pm 2.9 \mathrm{mg} / \mathrm{kg})$. Comparing the concentration of trace elements in the organs and tissues between crossbred sheep $(\mathrm{n}=6)$ and ZGWI goats $(\mathrm{n}=6)$, the goats had lower concentration of Se $(0.0136 \pm 0.002 \mathrm{mg} / \mathrm{kg}), \mathrm{I}(0.19 \pm 0.01 \mathrm{mg} / \mathrm{kg})$, and Co $(0619 \pm$ $0.03 \mathrm{mg} / \mathrm{kg}$ ) compared to sheep. Hematological profile of sheep and goats are indicated in table 2. By blood analysis, goats had higher $\mathrm{Hb}(50 \pm 0.8 \mathrm{~g} / \mathrm{l})$ than sheep, while sheep demonstrated higher level of RBC, by $2.64 \pm 1.210^{12} / 1$. The concentration of erythrocytes in goats was significantly higher than in sheep (difference, $5.5 \pm 0.6110^{9} / 1, \mathrm{P}<0.05$ ). The results of biochemical analysis of blood and serum of animals are indicated in table 3.

According to biochemical data, the uterine protein level was $14.67 \pm 2.7 \mathrm{~g} / \mathrm{l}$ higher in sheep than in goats but the total concentration of calcium was significantly higher in goats than in sheep, by $4.86 \pm 0.2 \mathrm{~mol} / \mathrm{l}$. For other indicators, the difference was not significant (Table 3). The "lipid peroxidation - antioxidant protection" system indicators of sheep and goats are shown in table 4. From data in table 4, it is evident that the level of conjugated dienes was $0.74 \pm 0.03 \mathrm{mmol} / \mathrm{ml}$ higher in sheep compared to goats, while the concentration of superoxide scavenger was by contrast higher in goats.

Table 1. The content of microelements in the organs and tissues of three years old ewes and goats in the biogeochemical conditions of the Lower Volga region (Mean \pm SEM)

\begin{tabular}{|c|c|c|c|c|c|c|}
\hline Organ (tissue) & $\begin{array}{l}\text { Selenium } \\
(\mathrm{mg} / \mathrm{kg})\end{array}$ & $\begin{array}{l}\text { Copper } \\
\text { (mg/kg) }\end{array}$ & $\begin{array}{c}\text { Cobalt } \\
(\mathrm{mg} / \mathrm{kg})\end{array}$ & $\begin{array}{c}\text { Manganese } \\
(\mathrm{mg} / \mathrm{kg})\end{array}$ & $\begin{array}{c}\text { Zinc } \\
(\mathrm{mg} / \mathrm{kg})\end{array}$ & $\begin{array}{l}\text { Iodine } \\
\text { (mg/kg) }\end{array}$ \\
\hline \multirow{2}{*}{ Skeletal muscle } & $0.026 \pm 0.004$ & $7.85 \pm 0.83$ & $0.06 \pm 0.003 *$ & $18.6 \pm 0.58$ & $73.2 \pm 2.11$ & $0.21 \pm 0.016^{*}$ \\
\hline & $0.02 \pm 0.005$ & $5.9 \pm 0.32$ & $0.04 \pm 0.002$ & $22.8 \pm 1.14$ & $78.3 \pm 7.42$ & $0.03 \pm 0.004$ \\
\hline \multirow{2}{*}{ Liver } & $0.57 \pm 0.003^{*}$ & $19.2 \pm 0.76^{*}$ & $3.06 \pm 0.08 *$ & $51.3 \pm 0.34 *$ & $98 \pm 5.35$ & $0.31 \pm 0.022 *$ \\
\hline & $0.32 \pm 0.06$ & $16.1 \pm 0.22$ & $2.09 \pm 0.84$ & $44.5 \pm 8.11$ & $116 \pm 12.3$ & $0.27 \pm 0.003$ \\
\hline \multirow{2}{*}{ Spleen } & $0.29 \pm 0.003$ & $16.5 \pm 2.24^{*}$ & $1.84 \pm 0.05^{*}$ & $52.6 \pm 0.18 *$ & $67.9 \pm 8.14^{*}$ & $0.8 \pm 0.19 *$ \\
\hline & $0.29 \pm 0.004$ & $14.8 \pm 1.06$ & $0.9 \pm 0.03$ & $33.7 \pm 1.09$ & $36.3 \pm 3.23$ & $0.08 \pm 0.002$ \\
\hline \multirow{2}{*}{ Blood } & $0.04 \pm 0.003$ & $8.7 \pm 0.87$ & $1.43 \pm 0.05^{*}$ & $55.7 \pm 0.09 *$ & $51.2 \pm 4.56^{*}$ & $0.36 \pm 0.113 *$ \\
\hline & $0.03 \pm 0.003$ & $12.7 \pm 1.95^{*}$ & $1.22 \pm 0.07$ & $49.6 \pm 3.14$ & $31.7 \pm 2.12$ & $0.21 \pm 0.021$ \\
\hline \multirow{2}{*}{ Lungs } & $0.09 \pm 0.003^{*}$ & $19.8 \pm 1.07$ & $1.03 \pm 0.004$ & $27.8 \pm 2.07$ & $93.2 \pm 3.54$ & $0.28 \pm 0.033$ \\
\hline & $0.07 \pm 0.001$ & $24.3 \pm 0.19^{*}$ & $0.83 \pm 0.003$ & $29.5 \pm 4.01$ & $106 \pm 5.19$ & $0.21 \pm 0.021$ \\
\hline \multirow{2}{*}{ Kidneys } & $0.03 \pm 0.008$ & $6.3 \pm 2.06^{*}$ & $0.94 \pm 0.0076^{*}$ & $42.2 \pm 2.05$ & $66.3 \pm 5.12$ & $0.42 \pm 0.017 *$ \\
\hline & $0.51 \pm 0.002 *$ & $13.9 \pm 0.05^{*}$ & $0.56 \pm 0.04$ & $46.8 \pm 2.18$ & $88 \pm 8.64 *$ & $0.26 \pm 0.004$ \\
\hline \multirow{2}{*}{ Abomasum } & $0.42 \pm 0.06^{*}$ & $16.1 \pm 1.08$ & $2.18 \pm 0.99 *$ & $53.3 \pm 1.08 *$ & $119 \pm 6.65$ & $0.54 \pm 0.09 *$ \\
\hline & $0.31 \pm 0.004$ & $14.5 \pm 0.06$ & $0.99 \pm 0.09$ & $45.3 \pm 1.28$ & $121 \pm 8.86$ & $0.32 \pm 0.09$ \\
\hline \multirow{2}{*}{ Small intestine } & $0.44 \pm 0.002$ & $19.3 \pm 1.26$ & $0.91 \pm 0.007$ & $40.1 \pm 0.31 *$ & $87.4 \pm 5.57 *$ & $0.47 \pm 0.017 *$ \\
\hline & $0.42 \pm 0.006$ & $20.1 \pm 0.05$ & $0.98 \pm 0.06$ & $25.6 \pm 2.05$ & $75.3 \pm 10.5$ & $0.25 \pm 0.017$ \\
\hline \multirow{2}{*}{ Bone tissue } & $0.07 \pm 0.003^{*}$ & $9.72 \pm 0.38^{*}$ & $1.28 \pm 0.05^{*}$ & $30.09 \pm 0.59$ & $124 \pm 3.24$ & $0.32 \pm 0.014$ \\
\hline & $0.03 \pm 0.017$ & $7.41 \pm 0.04$ & $1.02 \pm 0.006$ & $82.1 \pm 4.55 *$ & $161 \pm 9.8^{*}$ & $0.26 \pm 0.054$ \\
\hline \multirow{2}{*}{ Wool } & $0.26 \pm 0.004^{*}$ & $14.7 \pm 1.89^{*}$ & $4.25 \pm 0.04 *$ & $43.3 \pm 2.12 *$ & $96.8 \pm 4.27 *$ & $0.32 \pm 0.088^{*}$ \\
\hline & $0.12 \pm 0.08$ & $13.1 \pm 0.28$ & $3.16 \pm 0.08$ & $49.8 \pm 1.14$ & $56.7 \pm 3.12$ & $0.23 \pm 0.022$ \\
\hline
\end{tabular}

$* \mathrm{P}<0.05, \mathrm{n}: 12$ (6 sheep and 6 goats)

Table 2. Hematological profile of sheep and goats in the biogeochemical conditions of the Lower Volga region.

\begin{tabular}{|c|c|c|c|c|c|c|c|c|c|c|}
\hline \multirow{2}{*}{$\begin{array}{l}\mathrm{RBC} \\
10^{12} / 1\end{array}$} & \multirow{2}{*}{$\begin{array}{l}\mathrm{Hb} \\
\mathrm{g} / \mathrm{l}\end{array}$} & \multirow{2}{*}{$\begin{array}{c}\text { WBC } \\
10^{9} / 1\end{array}$} & \multicolumn{2}{|c|}{$\begin{array}{l}\text { Granular } \\
\text { leukocytes }\end{array}$} & \multicolumn{4}{|c|}{ Neutrophilic leukocytes } & \multicolumn{2}{|c|}{$\begin{array}{l}\text { Agranular } \\
\text { leukocyte }\end{array}$} \\
\hline & & & $\begin{array}{c}\text { BAS, } \\
\%\end{array}$ & $\begin{array}{c}\mathrm{EOS}, \\
\%\end{array}$ & $\begin{array}{c}\text { MIE, } \\
\%\end{array}$ & $\begin{array}{c}\mathrm{IN}, \\
\%\end{array}$ & $\begin{array}{c}\mathrm{BN}, \\
\%\end{array}$ & $\begin{array}{c}\mathrm{SN}, \\
\%\end{array}$ & $\begin{array}{c}\mathrm{LY}, \\
\%\end{array}$ & $\begin{array}{c}\mathrm{MO}, \\
\%\end{array}$ \\
\hline \multicolumn{11}{|c|}{ Soviet crossbred ewes for meat wool production $(n=6)$} \\
\hline $15.36 \pm 1.45$ & $103.6 \pm 3.8$ & $14.47 \pm 0.24$ & 0.4 & 5.09 & 0.1 & 0.0 & 1.5 & 43.5 & 46.0 & 2.5 \\
\hline \multicolumn{11}{|c|}{ Zaanen German White Improved goats $(n=6)$} \\
\hline $12.72 \pm 0.24$ & $153.4 \pm 0.82$ & $19.97 \pm 0.82$ & 0.2 & 2.1 & 0.2 & 0.0 & 4.5 & 25.2 & 65.5 & 2.1 \\
\hline
\end{tabular}

lymphocytes, $\mathrm{MO}=$ monocytes, $\mathrm{RBC}=$ red blood cell, $\mathrm{Hb}=$ hemoglobin, $\mathrm{WBC}=$ white blood cell, $\mathrm{g}=$ gram, $\mathrm{l}=$ liter. 
Table 3. Biochemical analysis of the serum samples of sheeps and goats in the biogeochemical conditions of the Lower Volga region (Mean $\pm \mathrm{SEM})$.

\begin{tabular}{lcc}
\hline Indicators & Sheep $(\mathbf{n}=\mathbf{6})$ & Goats $(\mathbf{n}=\mathbf{6})$ \\
\hline Total protein $(\mathrm{g} / \mathrm{l})$ & $73.61 \pm 5.02^{*}$ & $58.94 \pm 4.09$ \\
Total lipids $(\mathrm{g} / \mathrm{l})$ & $3.21 \pm 0.09$ & $4.35 \pm 0.08$ \\
Total calcium (mol/l) & $2.59 \pm 0.25$ & $7.45 \pm 0.14^{*}$ \\
Inorganic phosphorus (mol/l) & $1.34 \pm 0.07$ & $1.02 \pm 0.02$ \\
Selenium (ml/kg) & $0.042 \pm 0.002^{*}$ & $0.027 \pm 0.004$ \\
Iodine (mg/l) & $0.36 \pm 0.002^{*}$ & $0.21 \pm 0.006$ \\
Alkali reserve, volume \% $\mathrm{CO}_{2}$ & $43.4 \pm 2.75^{*}$ & $41.2 \pm 2.31$ \\
Glucose $(\mathrm{mol} / \mathrm{l})$ & $3.01 \pm 0.18$ & $4.97 \pm 0.33^{*}$ \\
Vitamins A (mol/l) & $0.86 \pm 0.004^{*}$ & $0.65 \pm 0.003$ \\
Vitamins $\mathrm{B}_{12}(\mathrm{mmol} / \mathrm{l})$ & $1.92 \pm 0.08^{*}$ & $1.65 \pm 0.06$ \\
Vitamins E (mmol/ml) & $6.21 \pm 0.03 *$ & $4.7 \pm 0.03$ \\
\hline
\end{tabular}

${ }^{*} \mathrm{p}<0.05$ in contrast to another animal species.

Table 4. The "lipid peroxidation - antioxidant protection" system indicators of sheep and goats in the biogeochemical conditions of the Lower Volga region (Mean \pm SEM).

\begin{tabular}{lcc}
\hline Indicators & Sheep $(\mathbf{n}=\mathbf{6})$ & Goat $(\mathbf{n}=\mathbf{6})$ \\
\hline Conjugated dienes $(\mathrm{mmol} / \mathrm{ml})$ & $2.04 \pm 0.03$ & $2.79 \pm 0.06^{*}$ \\
Malonic dialdehyde $(\mathrm{mmol} / \mathrm{l})$ & $0.42 \pm 0.06$ & $0.78 \pm 0.07^{*}$ \\
Catalase $(\mathrm{mmol}) \mathrm{H}_{2} \mathrm{O}_{2} /(\mathrm{l} \times \mathrm{min})$ & $3.09 \pm 0.05^{*}$ & $3.01 \pm 0.91$ \\
Glutathione peroxidase $(\mathrm{mmol}) \mathrm{GSH} /(\mathrm{l} \times \mathrm{min})$ & $6.07 \pm 0.17^{*}$ & $5.72 \pm 0.31$ \\
Superoxide scavenger $(\mathrm{unit} / \mathrm{min})$ & $161 \pm 9.15$ & $152 \pm 7.71$ \\
Peroxide resistance of erythrocyte $(\%)$ & $2.78 \pm 0.05$ & $3.21 \pm 0.09$ \\
\hline
\end{tabular}

*P<0.05 in contrast to another animal species.

\section{DISCUSSION}

The low contents of Se, I, and Co were found in samples of soil and pasture plants (Ermakov, 2017). At the same time, the content of $\mathrm{Mn}$ and $\mathrm{Zn}$ were at a comparable level in macrophyte with the chernozem region (black earth region) (Samokhin, 2003; Ermakov, 2017). The Cu content of all plant feeds studied was at the lower limit of the normal (Suttle, 2010; Ermakov, 2017).

The contents of Se, I and Co in the organs and tissues of sheep and goats were lower than the average values of small ruminants from other regions of Russia (Arsanukaev, 2006; Ochirov, 2015) and significantly below the physiological level (Motuzko et al., 2008; Goff, 2018). Therefore, the deficiency of Se, Co and I was determined in the main components of the ecosystems of the Astrakhan region of Russia. According to table 2, the concentration of erythrocytes (in sheep, $15.36 \pm 1.4510^{12} / 1$; in goats, $12.72 \pm 0.2410^{12} / 1$ ) and leukocytes (in sheep, $14.47 \pm 0.2410^{9} / 1$; in goats, $19.97 \pm 0.8210^{9} / 1$ ) was beyond the normal (Kondrakhin et al., 2004; Jones and Allison, 2007). Table 3 indicates that the concentration of biochemical analysis of blood and serum in sheep and goats was $0.1 \pm 0.001$ lower compared to the other regions (Müller et al., 1993; Arsanukaev, 2006). On the contrary, the content of glucose in the blood was above the normal values of physiological parameters (Kondrakhin et al., 2004; Motuzko et al., 2008). Se, Co and I deficiencies and associated metabolic changes in sheep and goats disrupted dynamic equilibrium in the lipids peroxidation antioxidant protection system (Table 4) and initiated the development of oxidative stress (Celi, 2011; Puppel et al., 2015).

Therefore, the conjugated dienes and malonic dialdehyde contained in sheep and goats' blood were significantly higher than the same small ruminants from regions with sufficient level of Se, Co and I in the environment and in the plants (Celi, 2011; Ochirov, 2015). The content of conjugated dienes and malonic dialdehyde in goats' blood was $36.8 \%$ and $85.7 \%$ higher $(\mathrm{P}<0.05)$ than sheep, respectively. The activity of catalase, glutathione peroxidase and superoxide dismutase in the blood of sheep and goats did not differ significantly, and the indicators were lower than the same small ruminants from regions with enough content of Se, Co, and I in the setting and plants (Ochirov, 2015). Data analysis has shown that therapeutic and preventive measures in the region are needed to offset the deficits of Se, Co and I in animal nutrition. 


\section{CONCLUSION}

The biogeochemical situation of the terrestrial ecosystems of the Lower Volga region was characterized by Se, Co, and I deficiencies in soil, water, pasture plants, diets, organs and tissues of Soviet Aksaray type crossbred sheep for meat and wool production and ZGWI goats. The deficiency of these trace elements in small ruminants had been compensated by changes in hematological (increased RBC and WBC) and biochemical blood parameters. The animals were recorded with a decrease in alkali reserve, the content of total protein and lipids, vitamins A, E, C, B12, total calcium, and inorganic phosphorus, increased in glucose, conjugated dienes and malonic di-aldehyde in the blood, and functional insufficiency of the antioxidant protection system.

\section{DECLARATIONS}

\section{Authors' contribution}

V. Vorobyov, D. Vorobyov, P. Polkovnichenko and V. Safonov and contributed equally to the experimentation. D. Vorobyov wrote and edited the article. P. Polkovnichenko and V. Vorobyov equally designed and conducted the experiment. V. Safonov studied scientific literature about the topic. All authors read and approved the final manuscript.

\section{Competing interests}

The authors declare that they have no competing interests.

\section{REFERENCES}

Arsanukaev DL (2006). Metabolism of various forms of microelements in young cattle and sheep, doctoral dissertation. Tver State Agricultural Academy, Tver. Available at:http://earthpapers.net/metabolizm-razlichnyh-form-mikroelementov-v-organizmemolodnyaka-krupnogo-rogatogo-skota-i-ovets

Bandeli FJ and Tuschhoff JV (1954). The microbiological determination of vitamin B12 utilizing a mutant strain of Escherichia coli. Journal of the American Pharmaceutical Association, 43(8): 474-477. DOI: https://doi.org/10.1002/jps.3030430809

Barnecki W (1960). Use of Kisiecki's method for the measurement of blood gases in the evaluation of alkaline reserve. Acta Physiologica Polonica, 11: 327-333. Available at: https://europepmc.org/abstract/med/13796857

Bevis LE (2015). Soil-to-human mineral transmission with an emphasis on zinc, selenium, and iodine. Springer Science Reviews, 3(1): 77-96. DOI: https://doi.org/10.1007/s40362-014-0026-y

Celi P (2011). Oxidative stress in ruminants. Studies on veterinary medicine. NJ: Humana Press, Totowa, pp. 191-231.

Diem H, Haferlach T and Theml H (2004) Color Atlas of Hematology: Practical Microscopic and Clinical Diagnosis. Thieme, New York. Available http://www.chospab.es/biblioteca/DOCUMENTOS/Color_Atlas_of_Hematology_Practical_and_Clinical_Diagnosis_2004_Thieme.pdf

Dinh QT, Li Z, Tran TAT, Wang D and Liang D (2017). Role of organic acids on the bioavailability of selenium in soil: A review. Chemosphere, 184: 618-635. DOI: https://doi.org/10.1016/j.chemosphere.2017.06.034

Ermakov VV (2017). AP Vinogradov's concept of biogeochemical provinces and its development. Geochemistry International, 55(10): 872-886. DOI: https://doi.org/10.1134/S0016702917100044

Georgievskii VI, Annenkov BN and Samokhin VT (1982). Mineral nutrition of animals, first edition. Butterworth Scientific Ltd, London. DOI: https://doi.org/10.1016/C2013-0-04148-5

Goff JP (2018). Invited review: Mineral absorption mechanisms, mineral interactions that affect acid-base and antioxidant status, and diet considerations to improve mineral status. Journal of Dairy Science, 101(4): 2763-2813. DOI: https://doi.org/10.3168/jds.2017-13112

Guemouri LYBCGG, Artur Y, Herbeth B, Jeandel C, Cuny G and Siest G (1991). Biological variability of superoxide dismutase, glutathione peroxidase, and catalase in blood. Clinical Chemistry, 37(11): 1932-1937. PMID: 1934468

Choleva TG, Gatselou VA, Tsogas GZ and Giokas D (2018) Intrinsic peroxidase-like activity of rhodium nanoparticles, and their application to the colorimetric determination of hydrogen peroxide and glucose. Microchimica Acta 185.1: 22. DOI:10.1007/s00604-017-2582-8

Hadwan MH and Ali SK (2018). New spectrophotometric assay for assessments of catalase activity in biological samples. Analytical biochemistry, 542: 29-33. DOI: https://doi.org/10.1016/j.ab.2017.11.013

Howard BJ, Wells C, Barnett CL and Sheppard SC (2016). How knowledge of the gastrointestinal absorption of elements could be used to predict transfer to milk. Scientific reports, 6: 37041. DOI: 10.1038/srep37041

Jones ML and Allison RW (2007). Evaluation of the ruminant complete blood cell count. Vet. Clin. N. Am-Food A, 23(3): $377-402$. DOI: https://doi.org/10.1016/j.cvfa.2007.07.002

Kabata-Pendias A (2001). Trace Elements in Soils and Plants, third edition. CRC Press, Boca Raton.

Kazimirskii AN, Poryadin GV, Salmasi ZM and Semenova LY (2018). Endogenous Regulators of the Immune System (sCD100, Malonic Dialdehyde, and Arginase). Bulletin of experimental biology and medicine, 164(5): 693-700. DOI: https://10.1007/s10517-018-4061-6 
Kondrakhin IP, Arkhipov AV, Levchenko VJ, Talanov GA, Frolova LA and Novikov VE (2004). Methods of veterinary clinical laboratory diagnostics. Kolos, Moscow.

Motuzko NS, Kudryavtseva EN and Brylo IV (2008). Physiological indicators of animals. Tekhnoperspektiva Press, Minsk.

Müller B, Kolb E, Dittrich H and Leo M (1993). The content of hemoglobin in the blood and the abundant and trace elements in blood plasma and erythrocytes of sheep, fallow deer, dwarf goats and reindeer. Tierärztliche Praxis, 21(2): 125-133. PMID: 8488500

Ochirov DS (2015). Violation of the trace element status of sheep and their correction with vitamin-mineral complexes. Stavropol State Agrarian University, Stavropol, Russia.

Paglia DE and Valentine WN (1967). Studies on the quantitative and qualitative characterization of erythrocyte glutathione peroxidase. The Journal of laboratory and clinical medicine, 70(1): 158-169. PMID: 6066618

Pokrovskii AA and Abrarov AA (1964). Peroxide resistance of erythrocytes. Voprosy Pitaniia, 23: 44-49. PMID: 14315490

Pryor WA and Castle L (1984). Chemical methods for the detection of lipid hydroperoxides. Methods in Enzymology, 105: 293-299. DOI: https://doi.org/10.1016/s0076-6879(84)05037-0

Puppel K, Kapusta A and Kuczyńska B (2015). The etiology of oxidative stress in the various species of animals, a review. Journal of the Science of Food and Agriculture, 95(11): 2179-2184. DOI: https://doi.org/10.1002/jsfa.7015

Samokhin VT (2003). Prevention of metabolic disorders of trace elements in animals, second edition. Voronezh State University Press, Voronezh.

Suttle NF (2010) Mineral nutrition of livestock, fourth edition. CABI Publication, London.

Urbánek L, Solichová D, Melichar B, Dvořák J, Svobodová I and Solich P (2006) Optimization and validation of a high-performance liquid chromatography method for the simultaneous determination of vitamins $\mathrm{A}$ and $\mathrm{E}$ in human serum using monolithic column and diode-array detection. Analytica Chimica Acta, 573: 267-272. DOI: https://doi.org/10.1016/j.aca.2006.02.032

Vorobyov DV (2012). The current biogeochemical situation in the Lower Volga region. LAP LAMBERT Academic Publishing $\mathrm{GmbH} \& \mathrm{Co}$, Saarbrucken.

Vorobyov V, Vorobyov D, Polkovnichenko A and Safonov V (2018). The physiological status of acclimatized Simmental cattle of the Austrian selection in the biogeochemical conditions of the Lower Volga region. American Journal of Agriculture and Forestry, 6(6): 198-207. DOI: https://doi.org/10.11648/j.ajaf.20180606.17

Woodman DD and Price CP (1972) Estimation of serum total lipids. Clinica Chimica Acta 38(1): 39-43. DOI: https://doi.org/10.1016/0009-8981(72)90205-7 